\title{
Radical and Moderate Enlightenment? The Case of Diderot and Kant
}

\begin{abstract}
I propose the hypothesis that, just as Hume woke him from his dogmatic slumber, and Rousseau revealed the universe of morality to him, Diderot left his mark on the political philosophy of Kant (as George Cavallar and Sankar Muthu note) upon detecting the coincidences between the two authors regarding their cosmopolitanism and anti-i.mperialism. Here, I begin with the distinction between a radical Enlightenment and a moderate Enlightenment, in order to show that in Kant both tendencies could have coexisted; which would explain the different readings of his thought, as is borne witness to by Heine's famous parable or Kant's continual dialogue with Spinoza. Despite having very different styles, the Kant of the 1790s could have been strongly influenced by the anonymous Diderot of the Encyclopédie or the History of the Two Indies. It seems quite clear that the critique of colonialism of Diderot-Raynal could have had a notable influence on the Kant of that decade-he of Theory and Praxis, Perpetual Peace, The Conflict of the Faculties and the Doctrine of Right (that is, the second part of the Metaphysics of Morals).
\end{abstract}

Die Wesen, deren Dasein zwar nicht auf unserm Willen, sondern der Natur beruht, haben dennoch, wenn si vernunftlose Wesen sind, nur einen relative Werth, als Mittel, und heissen daher Sachen, dagegen vernünftige Wesen Personen genannt werden, weil ihre Natur ist schon als Zwecke an sich selbst, d.i. als etwas, dass nicht bloss als Mittel gebracht werden darf, auszeichnet, mithin so fern als Willkür einschränkt (und ein Gegenstand der Achtung ist). (Imanuel Kant, Grundlegung, AA 04: 428).

Ces précepts singuliers, je les trouve opposes à la nature, contraires à la raison. Contraires à la nature, parce qu'ils supposent qu'un être sentant, pensant et libre peut être la propiété de'un être semblable à lui. Sur quoi ce droit serait fondé? Ne vois-tu pas qu'on a confundu dans ton pays la chose qui n'a ni sensibilité, ni pensée, ni désir, ni volonté, qu'on quitte et on prend, qu'on garde, qu'on n'éschange pas sans qu'elle souffre et sans qu'elle se plaigne, avec la chose qui n'échange point, qui ne s'acquiert point, qui a liberté, volonté, désir, qui se plaint et qui souffre, et qui ne saurait devenir un effect de commerce sans qu'on oublie

This article is a deliverable of the projects WORLDBRIDGES (F7-PEOPLE-2013-IRSES: PIRSES-GA2013-612644), PRISMAS (FFI2013-42395-P), NEW-TRUST-CM (S2015-HUM-3466 / DER2015-71755REDT) and PRX16/00482.

Roberto R. Aramayo, Instituto de Filosofía del Consejo Superior de Investigaciones Científicas (IFS-CSIC)

๑ OpenAccess. (c) 2018 Roberto R. Aramayo, published by De Gruyter. (cc) BY-NC-ND This work is licensed under the Creative Commons Attribution-NonCommercial-NoDerivatives 4.0 License. https://doi.org/10.1515/9783110492415-023 
son caractère et qu'on fasse violence à la nature? (Denis Diderot, Supplément au voyage de Bougainville, OC 03: 555).

\section{Two Enlightenments?}

Authors such as Philipp Blom and Jonathan Israel note that one should distinguish two Enlightenment traditions, one moderate and another much more radical. This thesis has been presented in two relatively recent books, both from 2010. I am referring to A Wicked Company: The Forgotten Radicalism of the European Enlightenment and A Revolution of the Mind: Radical Enlightenment and the Intellectual Origins of Modern Democracy (by Blom and Israel respectively).

According to Blom, Kant and Voltaire are the representatives of a moderate Enlightenment (reformist and deist), while the Encyclopedists, led by Diderot and D'Holbach, were committed to a materialist and revolutionary worldview that encouraged an enjoyment of living and promoted the right to live with dignity and in freedom, on the basis of a deeply immanentist philosophy. This second current was inspired by the Western tradition of freethinking, which extends from Epicurus and Lucretius up through Spinoza and Bayle, uses scepticism as a philosophical method and takes the analysis of the passions as the best guide for the understanding of human affairs.

Jonathan Israel further emphasizes that Bayle and Spinoza inspired the most radical ideas of the Encyclopedists, highlighting the fact that Robespierre and the Jacobins viewed the philosophes as being courtesans of absolutism, and instead glorified Rousseau and Voltaire, buried in the Pantheon as champions of the French Revolution. However, Israel notes that in reality, the change in mentality had been achieved by the Diderot of the Encyclopédie, together with other works that had a huge media impact on that era. This was especially the case for the Philosophical and Political History of European Settlements and Commerce in the Two Indies-a true engine of war against the structures of the Ancien Régime, particularly in the last section of the work, where its texts are both quantitatively and qualitatively significant.

According to the readings that Blom and Israel propose, these two contrary Enlightenment traditions had very little to do with one another, with the more radical current having impeded the success of the more moderate path. Nevertheless, although I sympathize greatly with their historiographical strategy, and even more with the effort to highlight the radical nature of the Enlightenment project in its totality, it seems to me that this emphasis should not overshadow the role played by presumably more moderate thinkers. We must redeem Diderot, who is without doubt the thinker that is the most contemporary to us 
among the philosophers of his age (Diderot 2009, p. 13-48)-but this should not mean forgetting about the decisive influence exercised on our chaotic times by such important authors as Rousseau and Kant.

As a result, it will be of interest to compare the possible confluences of these two contrary Enlightenment traditions and ask ourselves, for example, whether two of their most outstanding representatives, i.e. Kant and Diderot, are in fact completely antagonistic thinkers, as would be suggested by the strict distinction between the moderate and the radical currents of the Enlightenment; or is there, as I venture to suggest in this inquiry into the possible traces left by Diderot's thought in Kantian philosophy, some family resemblance that reveals a common ancestry?

Indeed, the intellectual circle close to Kant included Raynal, especially thanks to the presence of the abbé at the court of Frederick II (Barcarel 2011, p. 91). Kant himself cited the German translation of the History of the Two Indies in one of the editions of his Physical Geography (Kant 1816, p. 223: AA 26.1: 280), commenting on the Dutch East Indies Company, which he criticized so much in Perpetual Peace. Reconstructing Kant's access to the work of Diderot-Raynal is a tremendously arduous task-one already begun in Jean Ferrari's work Les sources françaises de la philosophie de Kant (Ferrari 1979). Simone Goyard-Fabre calls it a mysterious path, and suggests that the researcher will need the investigative skills of a detective due to the very few precedents we have (Goyard-Fabre 1996, p. 127; Quintili 2009, p. 75-89).

\section{Spinoza inside both Enlightenment traditions}

Just as many authors of the radical Enlightenment did, Kant maintained a continual dialog with Spinoza (De Flaviis 1986), beginning with his pre-critical writings and continuing through the Opus postumum, and featuring in his Lectures and in the Reflections he noted down for himself. Spinoza, the alma mater of the radical Enlightenment, remained for Kant the example of the virtuous atheist, the possibility of whose existence Pierre Bayle had upheld, as we read in the 87th paragraph of the third Critique-a paragraph added to its second edition (KU, AA 05, p. 427). On many occasions, Kant described Spinoza as someone of a good heart who behaved as a religious man would do; an atheist who acted morally despite not believing that any superior being would reward his good behaviour with the gift of the supreme good.

On the other hand, that substrate of nature that goes beyond the sensible, and which would be common to mechanism and teleologism, that Something (Etwas, with the capital letter; KU, AA 05, p. 466) that Kant referred to in the Cri- 
tique of Judgment, would relax Kant's famous dualism and bring him closer to the monism of Spinoza (KU, AA 05, pp. 392-393). Indeed, he would recreate the latter's famous Deus sive Natura when, in the Opus posthumum, he identifies God with self-legislating ethical-practical reason (OP, AA 21, p. 145), since the moral law resides within us and merits worship comparable to that historically rendered to divinity.

One of the sources through which Kant had access to Spinoza may have been the article on Spinozism in the Encyclopédie, where Diderot ascribes his own materialism to modern Spinozism (which should not be confused with the older variety, since for the modern thinker there is nothing but matter). Beginning in his first work, The Skeptic's Walk, Diderot uses Spinozism to mediate between deists and atheists (Diderot 2016, p. 115). The deist reproaches the atheist for leaving everything in the hands of chance; the atheist responds that one cannot describe the author of an infinite composite whose beginnings, current and final state are unknown; and the Spinozist seeks the origin of the universe within himself, via a careful study of the place that we occupy in it, just as Kant would do with moral law. One might also ask whether Spinoza's Ethics, Demonstrated in Geometrical Order isn't one of the reasons that Kant wrote part of the Analytics of his Critique of Practical Reason in a mathematical style, employing definitions, theorems, scholia, problems, demonstrations and postulates (Aramayo 2013a, p. 22), even when they led to a thesis completely opposed to that of Spinoza's essay.

Spinoza does not seem to serve well as a criterion for distinguishing the radical Enlightenment thinkers from the moderates, given that both Diderot and Kant share an admiration for and interest in him, as has been the case for a good portion of modern thinkers. In some way, the case of Spinoza bears witness-as I stated earlier in regard to Raynal-to the fact that the walls between the representatives of both tendencies of the Enlightenment project are quite porous. It would thus be wrong to treat the thought of the thinkers on each side as residing in sealed or even contradictory compartments.

\section{Heine's testimony}

Of course, it would be difficult to make Kant fit entirely within the limits of the moderate Enlightenment if one accepts how Heine describes him in On the History of Religion and Philosophy in Germany. The passage in question is wellknown, thanks to its extraordinary rhetorical appeal. Heine tells the French that they are much more prudish than the Germans. After taking the Bastille, the only thing the French managed to do was kill a king, who had in fact already lost his head long before he had been decapitated. In reality, Heine continues, 
one does too much honour to Robespierre when one compares him to Kant. Robespierre could lose his temper in bloody fashion, but when it came to the Supreme Being, he washed his bloody hands and put on his Sunday clothes. In contrast, the ruthless Kant was able to storm the heavens, annihilating their entire garrison and even the soldiers of their ontological, cosmological and psychotheological corps. God himself, now lacking even a demonstration of his own existence, has succumbed, and there is no longer any divine mercy, nor a Father's goodness, nor even any future recompense for present-day privations. The immortality of the soul is on its death bed. One hears nothing but moans and death rattles. In the face of this spectacle, the faithful servant Lampe becomes frightened and breaks out in tears. So Kant has pity on him and shows that he is not merely a great philosopher, but also a good man, using the magic wand of the practical reason to resuscitate the God that had been condemned by theoretical reason. It is very possible, adds Heine, that Kant undertook that resurrection not only because of compassion for Lampe, but also because he feared the police.

To finish off his clever and instructive piece of satire, Heine noted another subtle parallelism. Just as some had claimed that Robespierre was an agent of the British prime minister, there were also those who, in a totally confused manner, thought that Kant had made a secret pact with his adversaries, and that he had destroyed all the philosophical proofs of the existence of God in order to let the world know that one could never arrive at knowledge of God via one's reason, so as to imply that we should instead rely on revealed truth. This is the point of Heine's story that I wished to recall.

\section{Family resemblance between Diderot and Kant}

My hypothesis is that, while it might be very difficult to prove, it would not be strange if the influence of Diderot on Kant were similar to that of Rousseau (Aramayo 2015a, p. 53; 2005, p. 237-252; 2006, p. 17-54; 2016, p. 11-60; cf. 2017, p. 123-135), which Kant himself recognizes, and which is easy to trace in his texts, as I myself have emphasized on various occasions. Indeed, I have become ever more convinced that if the scepticism of Hume was able to wake Kant from his dogmatic slumber (Prol, AA 04, p. 260) and Rousseau opened the moral universe to him (HN AA 20, p. 44; cf. Aramayo, 2013b, p. 16-36), Diderot might have been the one who opened his eyes to the world of politics, through certain articles in the Encyclopédie and his anonymous contributions to the History of the Two Indies. In this view, Diderot may have had a great influence on Kant's political and even legal reflections-despite the fatc that Kant did not cite him, be- 
cause he did not know of his role in the authorship of these two collective works (which we nevertheless know that Kant read).

Recently more attention has been paid to the paradoxical intensity of this indirect relationship. Georg Cavallar, in a recent book about Kantian cosmopolitanism, relates that he was very surprised to discover that, in regards to hospitality and cosmopolitanism, Diderot was so close to Kant, despite the fact that "his publications did not form part of [Kant's] library, and it is not clear that he influenced him" (Cavallar 2015, p. 60).

It was certainly not unusual that Kant lacked a copy of the Encyclopédie in his personal library, given how much it cost, but it would have been highly unlikely that he did not have access to it via the library of his university. The presence of the preliminary discourse attributed to D'Alembert, noted at the beginning, offers proof of the attention dedicated to this immense collective work. It is worth bearing in mind that as early as 1759, Kant had recommended to his students and correspondents (such as Herder and Hamann) that they read Diderot and the articles he wrote for the Encyclopédie-although he certainly lacked any knowledge of his authorship-and even proposed that Hamann translate some of them (cf. the letter of Georg Hamann to Kant of July 27, 1759, Br, AA 10, p. 9). This exchange of letters indirectly tells us that Kant knew the first volumes of the Encyclopédie and might have had access to such articles written by Diderot as "Political Authority", “Citizen”, "Eclecticism”, "Encyclopédie” and "Philosopher"and it is equally likely that he paid attention to the later volumes that appeared up through 1765.

Let us take a look at these lines of the article "Eclecticism":

\footnotetext{
The eclectic is a philosopher who, treading on prejudice, tradition, authority, in a word, everything that subjugates the masses, dares to think for himself, to trace things back to the clearest general principles, examine them, discuss them, to admit nothing except what the testimony of his experience and his reason tells him; and on the basis of all the philosophies that he has analysed without partiality creates a philosophy that is his own. He is not at all a man who plants or sows, but rather one who gathers and winnows [italics RRA].
}

This text is later echoed by Kant, beginning with that 'winnowing' that must subject everything to the sieve and strainer of reason itself (albeit without forgetting experience) and putting aside the prejudices that arguments from authority invariably involve, since everything must be subjected to critique and to the tribunal of reason.

Diderot and Kant explicitly share one of the principal goals of the Enlightenment program. This daring to rely on one's own understanding, which Kant identifies as the banner of the Enlightenment, corresponds closely to the 'dar[ing] to think for yourself' that Diderot had formulated some years previously in his En- 
cyclopédie article. Both Kant and Diderot want to free the human being from all moral or political tutelage and to advocate an Enlightenment that allows us to leave behind our 'guilty minority of age', to use the Kantian expression. Diderot envisages the Encyclopédie as having this same objective: its mission is to change the common way of thinking, promoting thinking for one's self thanks to those cross references that permit each reader to extract his own conclusions, by combining different perspectives on a single problem (Aramayo 2012, p. 357385; 2015b, p. 319-338). In What is the Enlightenment?-a text from 1784, the year in which Diderot died-Kant advocates an 'authentic reform in our way of thinking' that would annihilate prejudices. The dynamic of the public use of reason, together with the Kantian consciousness of the pragmatic reality of our human condition, could well reflect an attempt to compose something analogous to what Diderot designed with the great project of the Encyclopédie.

In Pro and Contra, Diderot holds that "posterity is for the philosopher what the other world is for the religious man"-something that, as I have maintained elsewhere, Kant would subscribe to with his philosophy of history, where the postulate of the immortality of the soul is translated to that asymptotic meeting of the species with its destiny that marks the handover to the new generation (Aramayo 1992, p. 114-115). Similarly, the end of the Idea for a Universal History with a Cosmopolitan Purpose proposes a 'philosophical history' with a clearly political purpose, i.e. the channelling of the ambition of the heads of State and their servants towards the only means that can enable them to 'conquer a glorious memory in posterity' (WA, AA 08. p. 31). Here Kant is speaking very like Diderot, who speaks of monuments carved in the memories of men, consecrated to the champions of freedom and technical inventions, who he personifies at one point in the figures of Las Casas and Benjamin Franklin respectively (Skrzypeck 1995, p. 79-88).

Another set of traits that might reveal a family resemblance between Diderot and Kant are the esoteric and exoteric aspects of our two authors. After the traumatic experience of being imprisoned at Vincennes, Diderot decided to fool the censors with the cross references of the Encyclopédie and his anonymous pages in the History of the Two Indies, abandoning his novels and other writings in a drawer, hoping that they might be enjoyed by posterity. Kant also used a different style in his classes (in which, apart from his most lay-oriented courses, he was obligated to follow a textbook) than he did in his published writings and in the Reflections that he wrote strictly for himself. It is as though he had wanted his Nachlass to find another kind of readership with the passage of time-something very much in agreement with his distinction between a public use of reason (intended for an educated universe of readers) and a private use in the exercise of a trusted function (WA, AA 08, p. 37). 


\section{Cosmopolitanism, anticolonialism ${ }^{1}$ and the Rights of Man}

Whatever the case may be, there is at least one author who has clearly highlighted the Kantian debt to a Diderot immersed in political intervention. Sankar Muthu, in his book Enlightenment against Empire, argues that Diderot's radical political and historical writings appear to have had an influence on Kant, and goes so far as to hold that "in many regards Kant represents the spirit, and on occasion the letter, of Diderot's anti-imperialism" (Muthu 2003, p. 123)-so much so that certain aspects of his political philosophy can be said to be cut from the same cloth. Georg Cavallar, despite not providing any conclusive proofs, also emphasizes the analytic coincidences between the idea of cosmopolitanism in Kant and in Diderot (Cavallar 2015, p. 60 - 63). For the latter also distinguishes, in his contribution to the History of the Two Indies, between a right of necessity, a right of visitation, a right to be a guest and a right to establish oneself in a territory, making the right of visitation a perfect right in the case that the traveller's life is in danger. In contrast, the right to be the guest of a foreigner would be imperfect and contingent, and would only be activated if there was an agreement between the two parties. This is a classification very close to what Kant provides in Perpetual Peace, where he distances himself substantially from the principles of traditional international law, which tended much more strongly to legitimate the right of European peoples to settle in the New World.

Another point at which Diderot and Kant fully coincide is their clear anticolonialism (Benot 1970), which in the case of the latter really began to flower beginning in the second half of the 1790s. Furthermore, what Pauline Kleingeld has called Kant's second thoughts on colonialism-and, a little earlier, Kant's second thoughts on race (Kleingeld 2007, p. 573-592; 2014, p. 43-67)-which she sees as a somewhat capricious change in approach on his part, could have been due to his reading of the Diderot-Raynal work.

Of course, the symmetry of their approaches must be viewed through the prism of two different styles that respond to equally diverse personalities and circumstances. This occurs when Kant, in his Doctrine of Right, rejects as reprehensible the colonization of new lands that had been previously occupied by force or by fraudulent purchase, making use of European superiority, and without taking into account their prior possession, in order to give the savage peoples a legal

1 For a more extensive treatment of what I have noted here, I refer the reader to my forthcoming work coauthored with Nuria Sánchez Madrid. 
status, something that would validate the use of any dishonourable means whatsoever, and which he judges to be a cloak for injustice, or 'Jesuitism' (MS, A 06, p. 266). For his part, the Diderot of the Supplement refers to Jesuitism with a very different style, offering this description of the Jesuits in Paraguay:

Those cruel Spartans in black habits behaved with their Indian slaves like the Lacedaemonians with their helots: they condemned them to continual work, they gave them no right to property, they kept them brutish and tied down with superstition, they demanded deep veneration from them, walked among them with a whip in hand and lashed every age and sex without distinction. (Supplement, OC II:, p. 542)

The critique that Kant directed at colonialist practices at the end of his life parallels in good measure the demand that should be made of the traders, missionaries and emissaries of European powers, i.e. that they behave in a respectful way towards the law that should rule over their contacts with the so-called 'savages'. In Diderot's view, European nations should judge their behaviour by placing themselves in the place of the other. Just as Kant does, he criticizes the fact that when European voyagers come to a region of the New World that is not occupied by any people of the Old World, they immediately decide that that land belongs to them.

What would they think if some savages, upon landing upon their coasts, did something similar? How can they claim any right at all over men who are similar to them, or over the products of their lands?

\footnotetext{
For isn't the nature of property the same in every land, based on taking possession through work, and on a long and pacific enjoyment? Europeans, can you tell me at what distance from your residence this sacred title becomes invalidated? At twenty paces? At ten leagues? You say not. Well then, neither does it lose effect at ten thousand leagues. (Of the Colonies in General, OC III, p. 697)
}

Subscribing avant-la-lettre to one of the pillars of Kantian cosmopolitan law, Diderot speaks to us of the 'hospitality' that voyagers have had the occasion to enjoy, for instance in Brazil. He also coincides with Kant in holding that the spirit of commerce is a guarantee of peace, since a war between nations of traders is like a devastating fire, when bankruptcies become a question of State. Although Kant is not as explicit in his theses concerning non-European cultures, it is perhaps precisely for that reason that his reflections have a deeper theoretical basis and have been as much or more fecund than those put forth by Diderot. Without doubt, the Kantian approach pays more attention to the legal difficulties that the European powers encountered in justifying their occupation and annexation of territories on other continents, which leads him to emphasize the rights acquired over their territories by peoples without States. As K. Flikschuh has emphasized, 
what is most characteristic of Kant's legal cosmopolitanism is his attention to the form, i.e. to the mere formality of the contact that should take place between different peoples, independently of their degree of civil maturity.

A final coincidence that I would like to emphasize, in this inquiry into a possible family resemblance between the political philosophies of Diderot and Kant, is the enthusiasm they had for the American and French revolutions. In a famous note to paragraph 65 of the Critique of Judgment, Kant refers to the French Revolution as an example of the transformation of a political body into a true organism (although we do not have any evidence of any similar reactions to the American Revolution). Diderot, who could not opine on the French Revolution, since he had died five years prior, did comment on the American one, which in his judgment could provide:

... all the inhabitants of Europe with a refuge against fanaticism and tyranny, and instruct those who govern men on the legitimate use of authority, aiding in the prevention of an extremely unequal distribution of wealth and the corruption of morals. (Essay on the Reigns of Claudius and Nero, OC I, p. 1197)

For his part, as is well known, the Kant of the Conflict of the Faculties makes the French Revolution into a landmark of the moral progress of humanity; and he goes on in even more depth in Reflection 8077, but I will refrain from going into greater detail regarding these well-known texts.

\section{Conclusion}

In my view, the Kant of the 1790s, i.e. the author of Theory and Practice, Perpetual Peace, The Metaphysics of Morals and The Conflict of the Faculties, becomes more intelligible if we postulate that he knew (though in what was surely an unconscious manner) the battle writings of Diderot-those two intellectual engines of war that are the Encyclopédie and the History of the Two Indies.

I would like to say that Kant read Diderot, without knowing he did so, and that the latter revealed to him the global condition of politics, just as Rousseau had done for him regarding the moral universe. Thus, I believe that it is plausible to claim that Diderot had an impact on the political thought of Kant. "Force me to be silent about religion and government, and I will have nothing else to say", says Diderot in The Skeptic's Walk, and it is precisely to these two topics-the throne and the altar-that Kant dedicates his writings of the 1790s, probably under the unknown influence of Diderot. 


\section{Bibliography}

All references (unless otherwise indicated) to Denis Diderot's Works are in accordance with Diderot, Denis (1994-1995): Oeuvres. Laurent Versini (Ed.), Paris: Garnier Robert Laffont, 19941995. References indicate OC and volume followed by page number

All references (unless otherwise indicated to Immanuel Kant's works are in accordance with the Akademie Ausgabe (AA), Vol. 1-29 of Kants Gesammelte Schriften, Berlin/Leipzig, 1902-. References indicate volume followed by page number. Unless otherwise indicated, the English translations are from the Cambridge Edition of the Works of Immanuel Kant (Ca) (New York: Cambridge University Press, 1992-). The follwing abreviations are used along the paper.

$\mathrm{Br} \quad$ Briefe, AA 10-13.

HN Handschriftlicher Nachlass, AA 14-23.

KU Kritik der Urteilskraft (1790), AA 5: 167-485.

MS Die Metaphysik der Sitten (1797), AA 6: 205-492.

OP Opus postumun, AA 21-22.

Prol Prolegomena zu einer jeden künftigen Metaphysique (1783), AA 4.

WA Beantwortung der Frage: Was ist Aufklärung? (1784), AA 8: 35-42.

Aramayo, Roberto R. (1992): Crítica de la razón ucrónica. Madrid: Tecnos.

Aramayo, Roberto R. (2005): "Las claves rousseaunianas del concepto kantiano de Ilustración”. In: Revista Latinoamericana de Filosofía, vol. XXXI, No. 1, pp. 237-252.

Aramayo, Roberto R. (2006): "Carta preliminar en torno a la correspondencia de Rousseau y su apuesta 'kantiana' por una primacía moral”. In: Jean-Jacques Rousseau, Cartas morales y otra correspondencia filosófica. Madrid, México: Plaza y Valdés, pp. 17-54.

Aramayo, Roberto R. (2012): “Diderot y su revolución del pensar por sí mismo”. In: Birulés, Fina / Gómez Ramos, Antonio / Roldán, Concha (Ed.), Vivir para pensar. Homenaje a Manuel Cruz. Barcelona: Herder, pp. 357-385.

Aramayo, Roberto R. (2013a): “La biblia de la filosofía moral moderna y contemporánea”. In: Immanuel Kant, Crítica de la razón práctica. Madrid: Alianza Editorial, pp. 7-63.

Aramayo, Roberto R.(2013b): “La política y su devenir histórico en el pensamiento de Kant”. In: Ideas y Valores, Suppl.1, pp. 16-36.

Aramayo, Roberto R. (2015a): Rousseau: Y la política hizo al hombre. Barcelona: Bonalletra Alcompas.

Aramayo, Roberto R. (2015b): “Diderot, l'Encyclopedie et l'opinion publique”. In: Revue Roumaine de Philosophie 59/2, pp. 319-338.

Aramayo, Roberto R. (2016): "Los Ensueños de Rousseau: una cartografía de nuestra conciencia moral y civil”. In: Rousseau, Jean-Jacques: Ensoñaciones de un paseante solitario y otros escritos autobiográficos. Madrid: Plaza y Valdés, pp. 11-60.

Aramayo, Roberto R. (2017): "Spuren Rousseaus in Werk Kants. Erziehung, Gesellschaft, Kosmopolitismus”. In: Wagner / Astrid, Asmuth, Cristoph / Roldán, Concha (Eds.): Harmonie, Toleranz, kulturelle Vielfalt. Aufklärische Impulse von Leibniz bis zur Gegenwart. Würzburg: Könighausen \& Neumann, pp. 123-135.

Aramayo, Roberto R. / Sánchez Madrid, Nuria (forthcoming): “Ambigüedades del cosmopolitismo. Kant y Diderot frente a los abusos del colonialismo". In: VV.AA: Legados del cosmopolitismo ilustrado -forthcoming 
Barcarel, Gilles (Ed.) (2011): Raynal et ses réseaux. Paris: Champion.

Benot, Yves (1979): Diderot, de l'athéisme à l'anticolonialisme. Paris: Maspero.

Cavallar, George (2015): Kant's Embedded Cosmopolitanism. History, Philosophy and

Education for World Citizens. Berlin, Boston: Walter de Gruyter.

Diderot, Denis (2009): Pensamientos filosóficos. El combate de la libertad. Introduction by

Roberto R. Aramayo. Barcelona: Proteus.

Diderot, Denis (2016): El paseo del escéptico. Epilog by Roberto R. Aramayo. Pamplona:

Laetoli.

De Flaviis, Giuseppe (1986): Kant e Spinoza. Firenze: Sansoni Editore.

Ferrari, Jean (1979): Les sources françaises de la philosophie de Kant. Paris: Klincksieck.

Flikschub, Karin: “Colonial Mentality: Kant's Hospitality Right Then and Now”, in Flikschuh, K. / L.Ypi (eds.), Kant and Colonialism. Historical and Critical Perspectives, Oxford, OUP, 2014.

Goyard-Fabre, S. (1996): La philosophie du droit de Kant. Paris: Vrin.

Kant, Immanuel (1816): Immanuel Kants physische Geographie. Vol. 2 (1), 2nd ed., Berlin.

Kleingeld, Pauline (2007): “Kant's Second Thoughts on Race”. In: The Philosophical

Quarterly, vol. 57, no. 229, pp. 573-592.

Kleingeld, Pauline (2014): "Second Thoughts on Colonialism". In: Flikschuh, Katrin / Ypi, Lea (Eds.): Kant and Colonialism. Historical and Critical Perspectives. Oxford: Oxford University Press, pp. 43-67.

Muthu, Sankar (2003): Enlightenment against Empire. New Jersey: Princeton University.

Quintili, Paolo (2009): “Ëthique universaliste, politique révolutionnaire. Un rapport, un problème ouverte. Diderot, Raynal, Kant”. In: Bloch, Olivier (Ed.): L'idée de révolution: quelle place luir faire au XXI siècle? Paris: Publications de la Sorbonne, pp. 75-89.

Sánchez Madrid, Nuria (2014): “Kant y la crítica en clave jurídica del anticolonialismo".

Isegoría 53, pp. 727-736.

Skrzypeck, Marian (1995): “Comment l'homme s'eternise-t-il? Le Pour et le contre de Diderot et l' Histoire des deux Indes". In: Lüsenbrink, Hans-Jürgen / Strugnell, Anthony. L'Histoire des deux Indes: réecriture et polygraphie. Oxford: Voltaire Foundation, pp. 79-88. 